\title{
STRATEGI PROMOSI PEMASARAN DALAM UPAYA MENINGKATKAN PENJUALAN PADA PT. YAKULT INDONESIA PERSADA CABANG BANDAR LAMPUNG
}

\author{
Nia Fitriani ${ }^{(1)}$, Nur'aeni(2), Andi Mulyadinata ${ }^{(3)}$ \\ Fakultas Ekonomi Universitas Sang Bumi Ruwa Jurai \\ niafitriani201@gmail.com,nuraeni@fe.saburai.ac.id,andi.mulyadinata@fe.saburai.ac.id
}

\begin{abstract}
Abstrak. Objek penelitian adalah PT Yakult Indonesia Persada Cabang Bandar Lampung, Jl. Ryacudu, Perum Komplek Korpri Blok A7/21, Sukarame, Bandar Lampung. PT. Yakult Indonesia Persada merupakan satu dari sekian banyak perusahaan yang bergerak di bidang penjualan minuman kesehatan dengan bahan dasar susu fermentasi. Strategi pemasaran dilakukan dengan menggunakan direct selling (penjualan langsung). Masalah yang dihadapi adalah bahwa walaupun strategi promosi pemasaran berhasil meningkatkan jumlah penjualannya setiap tahun namun belum berhasil memenuhi target penjualan yang ditetapkan oleh perusahaan. Tujuan penelitian ini adalah untuk mengetahui dan menganalisis pengaruh strategi promosi pemasaran dalam upaya meningkatkan penjualan pada PT. Yakult Indonesia Persada Cabang Bandar Lampung. Adapun hipotesis penelitian yang diajukan yaitu "Strategi promosi pemasaran berpengaruh dalam upaya meningkatkan penjualan pada PT. Yakult Indonesia Persada Cabang Bandar Lampung". Pengumpulan data diperoleh melalui studi lapangan dengan populasi berjumlah 33 orang. Berdasarkan hasil penelitian disimpulkan bahwa strategi promosi pemasaran berpengaruh terhadap upaya meningkatkan penjualan pada PT. Yakult Indonesia Persada Cabang Bandar Lampung. Pengaruh ini didasarkan atas aktivitas promosi pemasaran dengan mengadakan eksebisi/pameran/kontes, dan pemberian potongan harga.
\end{abstract}

Kata Kunci : Promosi Pemasaran, Penjualan.

\section{PENDAHULUAN}

Persaingan yang semakin ketat di zaman yang cepat melalui perkembangan teknologi informasi menuntut para pelaku bisnis untuk mampu memaksimalkan kinerja perusahaannya agar terus dapat bersaing di pasar. Perusahaan harus berusaha keras untuk mempelajari dan memahami kebutuhan dan keinginan konsumennya. Dengan memahami kebutuhan dan keinginan konsumen, maka akan memberikan masukan penting bagi perusahaan untuk merancang strategi pemasaran yang tepat. Oleh karena itu untuk dapat mencapai kesuksesan di tengah persaingan yang ketat maka setiap perusahaan harus berusaha untuk mencapai tujuannya yaitu menciptakan dan mempertahankan pelanggan. Dalam mencapai tujuan tersebut perusahaan harus mampu menghasilkan barang maupun jasa yang diinginkan konsumen dengan tepat.

Kemudian untuk menghadapi persaingan antar perusahaan yang dewasa ini terus mengalami peningkatan maka setiap perusahaan membutuhkan strategi pemasaran. Fenomena persaingan antar perusahaan yang ada telah membuat setiap perusahaan mesti menyadari bahwa strategi yang tepatlah yang akan membantu perusahaan untuk dapat bertahan di tengah persaingan yang ketat tersebut. Dengan kata lain kunci utama perusahaan untuk memenangkan persaingan adalah melalui upaya mempengaruhi keputusan pelanggan, salah satunya adalah dengan strategi penyampaian produk melalui aktivitas promosi kepada konsumen. Penjualan merupakan suatu sumber pendapatan bagi perusahaan, semakin besar penjualan maka akan semakin 
besar pula keuntungan yang diperoleh perusahaan. Aktivitas ini merupakan pendapatan utama yang harus dikelola dengan baik agar tidak merugikan perusahaan.

Produk Yakult dipasarkan di berbagai lokasi, diantaranya di supermarket, minimarket dan warungwarung. Strategi pemasaran dilakukan dengan berbagai macam strategi di antaranya menggunakan Direct Selling yaitu dilakukan sampai dengan rumahrumah penduduk yang dipasarkan oleh para Yakult Lady secara door to door dan juga dilakukan melalui strategi promosi pemasaran yang dilakukan baik di supermarket, minimarket hingga toko-toko yang menjual produk Yakult. Produk Yakult memiliki ciri khas yaitu hanya terdiri dari satu rasa, satu warna dan tanpa adanya bahan pengawet ataupun zat pewarna buatan. Rasa dan warna Yakult dihasilkan dari hasil proses fermentasi, rasanya sedikit asam seperti yoghurt, dan warna yang dihasilkan adalah putih kekuningan. Selain itu, kemasan plastik yang ditutup dengan aluminium foil sebagai penutup botolnya merupakan khas lain dari atribut Yakult yang belum pernah berubah dari dulu.

Tabel 1. Tingkat Penjualan Minuman Yakult di Kota Bandar Lampung Tahun 2014 - 2018

\begin{tabular}{|c|c|c|c|c|}
\hline No. & $\begin{array}{l}\mathrm{Ta} \\
\mathrm{hu} \\
\mathrm{n}\end{array}$ & $\begin{array}{l}\text { Tingkat } \\
\text { Penjuala } \\
\mathrm{n} \\
\text { Minuma } \\
\mathrm{n} \text { Yakult }\end{array}$ & $\begin{array}{l}\text { Target } \\
\text { Penjuala } \\
\mathrm{n}\end{array}$ & $\begin{array}{l}\text { Pencapaian } \\
\text { Target }(\%)\end{array}$ \\
\hline 1. & $\begin{array}{l}20 \\
14\end{array}$ & 28.170 & 27.000 & 104,33 \\
\hline 2. & $\begin{array}{l}20 \\
15\end{array}$ & 28.780 & 29.000 & 99,24 \\
\hline 3. & $\begin{array}{l}20 \\
16\end{array}$ & 29.470 & 31.000 & 95,06 \\
\hline 4. & $\begin{array}{l}20 \\
17\end{array}$ & 30.690 & 33.000 & 93,00 \\
\hline 5. & $\begin{array}{l}20 \\
18\end{array}$ & 32.130 & 35.000 & 91,80 \\
\hline \multicolumn{2}{|c|}{ Jumlah } & 149.420 & 155.000 & 96,40 \\
\hline \multicolumn{2}{|c|}{ Rata-rata } & 29.848 & 31.000 & 96,40 \\
\hline
\end{tabular}

Sumber : PT Yakult Indonesia Persada Cabang Bandar Lampung, 2019.
Berdasarkan data pada Tabel 1 di atas terlihat bahwa tingkat penjualan Yakult di Kota Bandar Lampung mengalami peningkatan dari Tahun 2018 hingga Tahun 2018. Dengan pertumbuhan konsumsi minuman probiotik Yakult yang terus meningkat, hal ini meningindikasikan bahwa penjualan minuman probiotik Yakult memiliki prospek yang relatif baik dan diminati masyarakat khususnya di kota Bandar Lampung. Sayangnya peningkatan penjualan minuman Yakult ini cenderung belum berhasil mencapai target sebagaimana yang ditetapkan oleh PT Yakult Indonesia Persada Cabang Bandar Lampung, di mana hanya pada Tahun 2014 saja target penjualan berhasil terlampaui yaitu sebesar 104,33\%.

Berdasarkan uraian latar belakang masalah di atas, maka Penulis tertarik untuk melakukan penelitian yang dituangkan dalam bentuk Skripsi dengan judul "Strategi Promosi Pemasaran dalam Upaya Meningkatkan Penjualan pada PT. Yakult Indonesia Persada Cabang Bandar Lampung".

\section{KAJIAN TEORI}

\section{Pengertian Pemasaran}

Istilah pemasaran dalam Bahasa Inggris dikenal dengan nama marketing. Kata marketing ini boleh dikata sudah diserap ke dalam bahasa Indonesia, namun juga diterjemahkan dengan istilah pemasaran. Asal kata pemasaran adalah pasar (= market). Apa yang dipasarkan itu, ialah barang dan jasa. Pemasaran merupakan salah satu kegiatan pokok perusahaan dalam usaha mempertahankan kelangsungan hidup, berkembang dan memperoleh laba dengan cara menyesuaikan kemampuan perusahaan dengan kebutuhan konsumen. Berikut ini 
adalah pendapat beberapa ahli tentang pemasaran.

Menurut Kotler dalam Afif (2012 :

5) pemasaran adalah "Suatu proses sosial dengan mana individu dan kelompok mendapatkan apa yang mereka butuhkan dan inginkan dengan menciptakan dan mempertukarkan produksi dan nilai dengan individu dan kelompok lainnya".

Menurut Stanton dalam Swastha dan Irawan (2012 : 17) pemasaran adalah: "Suatu sistem keseluruhan dari kegiatankegiatan usaha yang ditujukan untuk merencanakan, menentukan harga, mempromosikan, mendistribusikan barang dan jasa yang memuaskan kebutuhan baik kepada konsumen atau pembeli yang ada maupun pembeli potensial".

\section{Pengertian Manajemen Pemasaran}

Manajemen pemasaran dapat didefinisikan sebagai suatu analisis perencanaan, pelaksanaan serta pengawasan program-program yang telah dirancang dalam hubungannya dengan pertukaranpertukaran yang diinginkan terhadap konsumen, yang ditujukan untuk memperoleh keuntungan pribadi maupun bersama. Hal ini terutama terletak pada penerapan serta koordinasi produksi, harga, distribusi dan promosi guna memperoleh hasil yang efektif.

Philip Kotler merumuskan pengertian manajemen pemasaran sebagai kegiatan menganalisa, merencanakan, mengimplementasi dan mengawasi segala kegiatan (program), guna memperoleh tingkat pertukaran yang menguntungkan dengan pembeli sasaran dalam rangka mencapai tujuan organisasi (Alma, 2013 : 130).

Definisi tersebut mengandung makna bahwa manajemen pemasaran :

a. Sebagai suatu proses manajemen yang meliputi analisis perencanaan, pelaksanaan dan pengawasan. b. Sebagai suatu kegiatan yang mempunyai tujuan untuk melahirkan pertukaran yang diinginkan.

c. Sebagai suatu kegiatan yang dapat dilakukan oleh penjual dan pembeli.

d. Sebagai suatu kegiatan yang dapat dilakukan baik yang bertujuan untuk keuntungan pribadi maupun bersama.

e. Sebagai suatu kegiatan yang difokuskan kepada penerapan dan koordinasi produksi, harga, distribusi dan promosi untuk mencapai hasil yang efektif.

\section{Pengertian Penjualan}

Penjualan merupakan salah satu fungsi pemasaran yang sangat penting dan menentukan bagi perusahaan dalam mencapai tujuan perusahaan yaitu memperoleh laba untuk menjaga kelangsungan hidup perusahaan.

Melakukan penjualan adalah suatu kegiatan yang ditujukan untuk mencari pembeli, mempengaruhi, dan memberi pembeli agar pembelian dapat menyesuaikan kebutuhannya dengan produksi yang ditawarkan serta mengadakan perjanjian yang ditawarkan serta mengadakan perjanjian mengenai harga yang menguntungkan kedua belah pihak. Kesimpulannya adalah bahwa penjualan adalah suatu kegiatan dan cara untuk mempengaruhi pribadi agar terjadi pembelian (penyerahan) barang atau jasa yang ditawarkan, berdasarkan harga yang telah disepakati oleh kedua belah pihak dalam kegiatan tersebut.

Swastha Basu Swastha (2014 : 406) membagi jenis-jenis penjualan sebagai berikut :

1. Trade Selling, Trade selling dapat terjadi bilamana produsen dan pedagang besar mempersilahkan pengecer untuk berusaha memperbaiki distributor produk- 
produk mereka. hal ini melibatkan para penyalur dengan kegiatan promosi, peragaan, persediaan dan produk baru.

2. Missionary Selling, Merupakan penjualan berusaha ditingkatkan dengan mendorong pembeli untuk membeli barang-barang dari penyalur perusahaan.

3. Technical Selling, Yaitu berusaha meningkatkan penjualan dengan pemberian saran dan nasehat kepada pembeli akhir dari barang dan jasanya.

4. New Businies Selling, Merupakan berusaha membuka transaksi baru dengan merubah calon pembeli menjadi pembeli.

5. Responsive Selling, Adalah setiap tenaga penjualan diharapkan dapat memberikan reaksi terhadap permintaan pembeli.

Pada umumnya para pengusaha mempunyai tujuan mendapatkan laba tertentu (mungkin maksimal), dan mempertahankan atau bahkan berusaha meningkatkannya untuk jangka waktu lama. Tujuan tersebut dapat direalisir apabila penjualan dapat dilaksanakan seperti yang direncakan. Dengan demikian tidak berarti bahwa barang atau jasa yang terjual selalu akan menghasilkan laba.

\section{Pengertian Strategi}

Strategi yang telah didefinisikan dalam beragam cara oleh banyak penulis. Amstrong (2003 : 37) menjelaskan bahwa strategi adalah penetapan tujuan dasar jangka panjang dan sasaran perusahaan, dan penerapan serangkaian tindakan, serta alokasi sumber daya yang penting untuk melaksanakan sasaran ini.

Menurut Rangkuti (2014: 3) strategi adalah alat untuk mencapai tujuan atau dapat dikatakan sebagai respon secara terus menerus, maupun adaptasi terhadap peluang dan ancaman eksternal, ataupun kekuatan dan kelemahan internal yang dapat mempengaruhi organisasi.

Menurut Assauri (2013: 7) fungsi dari strategi pada dasarnya adalah berupaya agar strategi yang disusun dapat diimplementasikan secara efektif. Fungsi strategi adalah sebagai berikut :

1. Mengkomunikasikan suatu maksud (visi) yang ingin dicapai kepada orang lain.

2. Menghubungkan atau mengaitkan kekuatan atau keunggulan organisasi dengan peluang dari lingkungannya.

3. Memanfaatkan atau mengeksploitasi keberhasilan dan kesuksesan yang dapat sekarang atau sekaligus menyelidiki adanya peluang-peluang baru.

\section{METODE PENELITIAN}

\section{Objek Penelitian}

Penelitian dilakukan di PT Yakult Indonesia Persada Cabang Bandar Lampung, Jl. Ryacudu, Perum Komplek Korpri Blok A7/21, Sukarame, Bandar Lampung. Adapun waktu penelitian skripsi ini dilakukan kurang lebih selama 3 (tiga) bulan yang dimulai pada Bulan Mei 2019 dan berakhir pada Bulan Juli 2019.

\section{Metode dan Teknik Pengumpulan Data}

Dalam penelitian ini jenis data yang diperlakukan adalah :

a. Data Primer

Data primer merupakan data yang diperoleh secara langsung dari objek yang diteliti yaitu pada PT Yakult Indonesia Persada Cabang Bandar Lampung.

b. Data Sekunder

Data Sekunder merupakan data yang diperoleh secara tidak langsung baik dari literatur-literatur ataupun dari bahan-bahan 
tertulis yang berkaitan dengan permasalahan yang dibahas dalam penulisan skripsi ini.

Langkah-langkah pengumpulan data yang penulis lakukan dengan mengadakan penelitian lapangan, adapun teknik yang digunakan dalam pengumpulan data adalah dengan :

1. Observasi, yaitumengadakan survey atau pengamatan langsung kelokasi penelitian.

2. Interview atau wawancara, yaitu mengadakan tanya jawab langsung dengan pegawai.

3. Dokumentasi, yaitu mengumpulkan dan mencatat dokumentasi yang relevan.

4. Quisioner, yaitu membuat pertanyaan yang berhubungan dengan varibael penelitian.

\section{Sampel dan Populasi}

Populasi adalah wilayah generalisasi yang terdiri atas obyek/subyek yang mempunyai kualitas dan karakteristik tertentu yang ditetapkan oleh peneliti untuk dipelajari dan kemudian ditarik kesimpulannya (Sugiyono, 2017 : 72).

Populasi yang ditetapkan di dalam penelitian ini adalah tenaga pemasaran pada PT Yakult Indonesia Persada Cabang Bandar Lampung yang berjumlah 33 orang di mana seluruhnya dijadikan sebagai responden penelitian, sehingga penelitian ini dapat disebut sebagai penelitian populasi.

\section{Metode Analisis Data}

Analisis kualitatif adalah analisis yang menggambarkan secara rinci, dengan interpretasi terhadap data yang diperoleh melalui pendekatan teoritis. Data yang diperoleh dari hasil angket untuk masingmasing variabel yaitu promosi pemasaran $(\mathrm{X})$, dan peningkatan penjualan $(\mathrm{Y})$ dengan menggunakan Skala Likert, di mana alternatif jawaban responden diberikan skor 1 sampai 5, dengan rumus interval sebagai berikut :

$$
I=N T-\frac{N R}{K}
$$

Keterangan :

I = interval total skor

NT = nilai total skor harapan tertinggi

$\mathrm{NR}$ = nilai total skor harapan terendah

$\mathrm{K}$ = jumlah alternatif jawaban

Selanjutnya Untuk mengetahui pengaruh pembinaan karier (X) terhadap kinerja pegawai $(\mathrm{Y})$, rumus yang digunakan adalah sebagai berikut :

$$
Y=a+b X+E t
$$

Keterangan :

$\mathrm{Y} \quad=$ variabel peningkatan penjualan

$\mathrm{X} \quad=$ variabel promosi pemasaran

a $\quad=$ intercept

$\mathrm{b} \quad=$ koefisien regresi

Et =kesalahan penggunaan (error term) (Sugiyono, 2017 : 200)

Rumus hipotesis :

H0 : $0=0$ (Regresi tidak ada artinya bila dipakai untuk membuat kesimpulan)

H1 : $0 \neq 0 \quad$ (Regresi ada artinya bila dipakai untuk membuat kesimpulan)

Untuk mengetahui besarnya persentase pengaruh dari variabel bebas $(\mathrm{X})$ terhadap variabel terikat (Y), maka digunakan rumus Koefisien Determinasi (kd) sebagai berikut :

$$
K D=r^{2} \times 100 \%
$$

Keterangan :

KD = Nilai Koefisien Determinasi

$\mathrm{r} \quad=$ Nilai Koefisien Korelasi

(Riduwan, 2015 : 136) 
Kemudian untuk menguji hipotesis penelitian maka digunakan Uji $\mathrm{t}$ dengan rumus, yaitu :

$$
t_{\text {hitung }}=\frac{\sqrt{n}-2}{\sqrt{1}-r^{2}}
$$

(Riduwan, $2015: 137$ )

Kriteria pengujian signifikansi :

a. Jika $t_{\text {hitung }} \geq \mathrm{t}_{\text {tabel }}$, maka signifikan, artinya tolak Ho terima Ha.

b. Jika $t_{\text {hitung }}<t_{\text {tabel}}$, maka tidak signifikan, artinya terima Ho, tolak Ha. Taraf signifikansi yang digunakan alfa $=0,05$ atau $5 \%$.

\section{HASIL DAN PEMBAHASAN}

\section{Analisis Kuantitatif}

\section{Uji Regresi Linear}

Tabel Tabel Koefisien Regresi Promosi Pemasaran terhadap Penjualan Coefficientsa

\begin{tabular}{|c|c|c|c|c|c|}
\hline \multirow[b]{2}{*}{ Model } & \multicolumn{2}{|c|}{ Unstandardized } & \multirow{2}{*}{\begin{tabular}{|l}
$\begin{array}{l}\text { Standar } \\
\text { dized }\end{array}$ \\
Beta
\end{tabular}} & \multirow[b]{2}{*}{$\mathrm{t}$} & \multirow[b]{2}{*}{ Sig. } \\
\hline & B & $\begin{array}{l}\text { Std. } \\
\text { Error }\end{array}$ & & & \\
\hline 1 (Constant) & 21.848 & 5.055 & & 4.322 & .000 \\
\hline $\begin{array}{l}\text { Promosi_- } \\
\text { Pemasaran }\end{array}$ & .506 & .140 & .545 & 3.623 & .001 \\
\hline
\end{tabular}

a. Dependent Variable: Penjualan

Berdasarkan data pada Tabel di atas dapat dijelaskan bahwa analisis regresi menghasilkan arah regresi b sebesar 0,506 dan konstanta a sebesar 21,848. Dengan demikian pengaruh Promosi Pemasaran terhadap promosi pemasaran dapat digambarkan melalui persamaan regresi : $\hat{\mathrm{Y}}=21,848+0,506 \mathrm{X}$. Hasil ini menunjukkan apabila Promosi Pemasaran ditingkatkan sebesar 1 satuan (\%), maka akan dapat meningkatkan penjualan sebesar 0,506 satuan $(\%)$.

\section{Uji Koefisien Determinan}

Tabel Tabel Uji R Promosi Pemasaran terhadap Peningkatan Penjualan

\begin{tabular}{|l|l|l|l|l|}
\multicolumn{5}{c|}{} \\
$\begin{array}{l}\text { Mod } \\
\text { el }\end{array}$ & $\mathrm{R}$ & $\begin{array}{l}\mathrm{R} \\
\text { Square }\end{array}$ & $\begin{array}{l}\text { Adjusted } \\
\text { Square }\end{array}$ & $\begin{array}{l}\text { R } \\
\text { Std. Error of the } \\
\text { Estimate }\end{array}$ \\
\hline 1 & $.545 \mathrm{a}$ & .297 & .275 & 4.196 \\
\hline
\end{tabular}

a. Predictors: (Constant), Promosi_Pemasara

Berdasarkan hasil perhitungan di atas dapat diketahui nilai $\mathrm{R}$ adalah sebesar 0,545, sehingga pengaruh variabel Promosi Pemasaran terhadap variabel penjualan termasuk kategori sedang. Adapun nilai R2 (square) sebesar 0,297, artinya persentase pengaruh Promosi Pemasaran terhadap variabel peningkatan sebesar 29,7\%, sedangkan sisanya sebesar 70,3\% dipengaruhi oleh variabel lain.

\section{Uji Hipotesis}

Tabel Tabel Uji Hipotesis Promosi Pemasaran terhadap Peningkatan Penjualan Coefficientsa

\begin{tabular}{|c|c|c|c|c|c|}
\hline \multirow{2}{*}{ Model } & \multicolumn{2}{|c|}{$\begin{array}{l}\text { Unstandardize } \\
\text { d Coefficients }\end{array}$} & $\begin{array}{l}\text { Standar } \\
\text { dized } \\
\text { Coeffici } \\
\text { ents }\end{array}$ & $\mathrm{t}$ & Sig. \\
\hline & B & $\begin{array}{l}\text { Std. } \\
\text { Error }\end{array}$ & Beta & & \\
\hline 1 & 21.848 & 5.055 & & 4.322 & .000 \\
\hline Promosi_ & .506 & 140 & .545 & 3.623 & .001 \\
\hline
\end{tabular}

a. Dependent Variable: Penjualan

Hasil uji thitung diperoleh nilai sebesar 3,623 , sedangkan nilai $t_{\text {tabel }}$ untuk $\mathrm{n}=33$ pada $\square=0,05$ adalah 2,036. Dengan demikian nilai $t_{\text {hitung }}>t_{\text {tabel }}$ (tolak Ho, 
terima Ha), sehingga hasil tersebut menunjukkan hipotesis yang diajukan terbukti benar bahwa Strategi Promosi Pemasaran Berpengaruh terhadap Upaya Meningkatkan Penjualan pada PT. Yakult Indonesia Persada Cabang Bandar Lampung.

\section{KESIMPULAN DAN SARAN}

\section{Kesimpulan}

1. Strategi promosi pemasaran pada PT. Yakult Indonesia Persada Cabang Bandar Lampung belum mampu memenuhi target penjualan yang ditetapkan dengan rata- rata pencapaian target sebesar $96,40 \%$.

2. Pengaruh variabel Promosi Pemasaran terhadap variabel penjualan termasuk kategori sedang. Adapun persentase pengaruh Promosi Pemasaran terhadap variabel peningkatan sebesar 29,7\%, sedangkan sisanya sebesar $70,3 \%$ dipengaruhi oleh variabel lain.

3. Strategi promosi pemasaran berpengaruh terhadap upaya meningkatkan penjualan pada PT. Yakult Indonesia Persada Cabang Bandar Lampung. Pengaruh ini didasarkan atas aktivitas promosi pemasaran dengan mengadakan eksebisi/pameran/kontes, dan pemberian potongan harga.

\section{Saran}

Adapun saran dari penelitian ini adalah sebagai berikut :

1. Hendaknya Yakult Indonesia Persada Cabang Bandar Lampung harus lebih mengintensifkan kegiatan promosi pemasarannya terutama dengan lebih sering mengadakan promosi-promosi di tempat penjualan produk sehingga target penjualan dapat dicapai.
2. Hendaknya Yakult Indonesia Persada Cabang Bandar Lampung mengevaluasi program promosi pemasaran yang telah dilaksanakan selama ini sehingga dapat dievaluasi secara maksimal apa faktor yang menjadi penyebab tidak tercapainya target penjualan dalam lima tahun terakhir

\section{DAFTAR PUSTAKA}

Arikunto, Suharsimi. 2016. Prosedur Penelitian Suatu Pendekatan Praktik.Jakarta: Rineka Cipta.

Hurriyati, Ratih. 2010. Bauran Pemasaran dan Loyalitas Konsumen. Bandung: Alfabeta.

Kotler, Philip dan Amstrong. 2009. Manajemen Pemasaran. Jakarta: Indeks.

Rangkuti, Freddy. 2009. Strategi Promosi yang Kreatif dan Analisis Kasus Integrated Marketing Communication. Jakarta: Gramedia Pustaka Utama.

Rangkuti, Freddy. 2009. Mengukur Efektivitas Program Promosi \& Analisis Kasus Menggunakan SPSS. Jakarta: Gramedia Pustaka Utama.

Riduwan. 2015. Skala Pengukuran Variabel-Variabel Penelitian. Bandung: Penerbit Alfa Beta.

Swastha, Basu. 2014. Manajemen Penjualan. Yogyakarta: BPFE Yogyakarta.

Swastha, Basu dan Irawan. 2010. Manajemen Pemasaran Modern. Yogyakarta: Penerbit Liberty. 
Nia Fitriani : Strategi Promosi Pemasaran Dalam Upaya Meningkatkan Penjualan Pada Pt. Yakult Indonesia Persada Cabang Bandar Lampung

G.R, Terry. 2015, Dasar-dasar Manajemen, Edisi Revisi. Jakarta:Buku Beta.

Bruce J, Walker. (2014; 221). Sales Promotion, Jilid II.Jakarta: Penerbit Erlangga.

Grogoruis, Chandra. (2015;155). Pemasaran Sentrategij, Edisi II. Jakarta: ISBN.

Sugiyono. 2017. Metode Penelitian Bisnis. Bandung: Penerbit CV. Alfabeta

Tjiptono, Fandy. 2009. Manajemen Jasa.. Yogyakarta: Penerbit Andi Offset 